\title{
NITROGEN DOSES IN TOPDRESSING AFFECT VEGETATION INDICES AND CORN YIELD
}

\section{DESES DE NITROGÊNIO EM COBERTURA AFETAM ÍNDICES DE VEGETAÇÃO E PRODUTIVIDADE DE MILHO}

\author{
Fabio Henrique Rojo BAIO'; Eder Eujácio da SILVA; Igor Mendes SCARPIM; \\ Cid Naudi da Silva CAMPOS'; Paulo Eduardo TEODORO' \\ 1. Universidade Federal de Mato Grosso do Sul, Campus de Chapadão do Sul (UFMS/CPCS), \\ Chapadão do Sul, MS, Brasil. eduteodoro@ hotmail.com
}

\begin{abstract}
Nitrogen is the main nutrient required by corn crop, especially in Cerrado soils. Remote sensing techniques can be used to generate additional information now of nitrogen fertilization recommendation. This work investigated the association of plant height and dry matter phenological variables together with NDVI, REDEDGE, SAVI, and IV 760/550 vegetation indices (VIs) with corn grain yield, under different $\mathrm{N}$ doses. Sowing occurred in November 2016, at a spacing of $0.45 \mathrm{~m}$ between rows and a $60,000 \mathrm{ha}^{-1}$ plant population. Four $\mathrm{N}$ doses $\left(0,80,160\right.$, and $240 \mathrm{~kg}$ of $\left.\mathrm{N} \mathrm{ha}^{-1}\right)$ were applied at phenological stage V4. The experimental design consisted of randomized blocks, containing four $\mathrm{N}$ doses in topdressing and 16 replications. The active optical sensor Crop Circle ACS-470 was used to obtain the VIs. The NDVI, SAVI, and RE indices have a high positive association with each other and with the variables plant height and dry matter. Polynomial regression equations were adjusted between the variables in response as doses of $\mathrm{N}$. Afterwards, they were estimated as correlations between variables and results expressed through the network of correlations. Finally, a multivariate analysis of canonical variables was performed to understand the interrelationship between the variables and each dose of N applied. NDVI and RE have a positive relationship of moderate magnitude with grain yield in corn crops.
\end{abstract}

KEYWORDS: Multivariate analysis. Remote sensing. Correlation network. Zea mays.

\section{INTRODUCTION}

Brazil is among the world's three largest corn producers, with a production of 79.9 million tons of grain in the 2016/2017 harvest, and an average yield of $6.5 \mathrm{t} \mathrm{ha}^{-1}$ (CONAB, 2018). This yield can be increased, and the nitrogen (N) management is one of the main factors that need to be improved in this crop. $\mathrm{N}$ is one of the most difficult nutrients to manage in the soils of subtropical regions due to its high soil instability. This fact is because it is subject to a large number of interactions (ERNANI, 2003).

Remote sensing techniques can be used to generate additional information at the moment of nitrogen fertilization recommendation. Data from the spectral response of the crop canopy during its development, characterized by the process of reflectance of incident electromagnetic waves, can be used as indirect indicators of nutritional status and productive potential of a culture (SERRANO et al., 2000). Sensors that measure spectral properties, reflectance, and transmittance of plant leaves are affected by the Nitrogen concentration $(\mathrm{N})$ since this nutrient is essential to the chlorophyll molecule, which is the pigment that first absorbs the light energy necessary for photosynthesis (BLACKMER; SCHEPERS, 1995; TARPLEY et al., 2000).

Two wavelengths are directly related to plant variables, being indicators of the productive potential: red spectrum waves, whose reflectance is lower under a greater amount of chlorophyll (TUCKER, 1979); and infrared spectrum waves, whose reflectance is higher under a greater plant dry matter accumulation (DM). Leaf chlorophyll content and DM production positively correlate to $\mathrm{N}$ doses and yield (SCHADCHINA; DMITRIEVA, 1995). Vegetation indices are used to minimize the variability caused by external factors in the data obtained from reflectance, which are sensitive to the green biomass of the plants and, therefore, to the amount of chlorophyll per unit area (PONZONI, 2001).

Shaver et al. (2017) studied the efficiency of nitrogen use in corn crops and observed that canopy sensors could be an effective tool to determine the $\mathrm{N}$ doses in topdressing, mainly in irrigated fields, where fertirrigation can be used, and the several split applications can be conducted. Fang et al. (2014) studied the interaction between different 
vegetation indices (VIs) to estimate yield, obtaining errors of $3.5 \%$ in the estimate of field yield when using interaction, and $13 \%$, when using only one VI.

However, in-field data collection is costeffective, in which remote sensing helps guide sampling (MLADENOVA et al. 2017). The objective of this work was to study the phenological variables and different vegetation indices to estimate corn yield potential.

\section{CONTENTS}

The experiment carried out in the experimental area of the Federal University of Mato Grosso do Sul (lat. 18 46'17.9"S; long. $52^{\circ} 37 ' 25.0 " \mathrm{~W}$, alt. $810 \mathrm{~m}$ asl) during the 2016/17 harvest, in the municipality of Chapadão do Sul MS. The experimental design was randomized blocks with four urea doses and 16 replications. The experimental plots consisted of nine $4 \times 6 \mathrm{~m}$ rows, totaling 64 plots. The hybrid DKB 310 VT PRO $3^{\circledR}$ was used. At sowing, $30 \mathrm{~kg} \mathrm{ha}^{-1}$ of nitrogen (urea, $43 \% \mathrm{~N}$ ), $120 \mathrm{~kg} \mathrm{ha}^{-1}$ of phosphorus (super simple phosphate $20 \% \mathrm{P}_{2} \mathrm{O}_{5}$ ), and $60 \mathrm{~kg} \mathrm{ha}^{-1}$ potassium (Potassium chloride, 58\% $\mathrm{K}_{2} \mathrm{O}$ ) were applied. Sowing was carried out on November $12^{\text {th }}, 2016$, at a spacing of $0.45 \mathrm{~m}$ and a $60,000 \mathrm{ha}^{-1}$ population. When corn plants reached stage V4, at 22 days after emergence (DAE), the nitrogen fertilizer urea (43\% $\mathrm{N})$ was applied at doses of $0,80,160$, and $240 \mathrm{~kg}$ of $\mathrm{N} \mathrm{ha}^{-1}$

The three central rows were used for analyses, discarding $1 \mathrm{~m}$ of each end to avoid possible interference of other treatments, totaling a useful area of $5.4 \mathrm{~m}^{2}$. At $64 \mathrm{DAE}$, the following variables were evaluated: plant height $(\mathrm{PH})$, using a graduated ruler; vegetation indices (VI) [NDVI (Normalized Difference Vegetation Index), RE (REDEDGE), SAVI (Soil-Adjusted Vegetation Index), and VI 760/550], with a Crop Circle sensor, model ACS-470 (Holland Scientific, Lincoln, EUA), using the filters 550, 670, 730, and $760 \mathrm{~nm}$; shoot dry matter (SDM), by randomly collecting three plants in the plot, which were cut at the stem. The material was stored in paper bags, dehydrated in an oven at $105{ }^{\circ} \mathrm{C}$ for 48 hours, and weighed. The means of the three evaluated plants were processed.

For the $\mathrm{N}$ doses applied in topdressing and each evaluated variable, maps were generated by the ESRI ArcGis 10.5 Geographic Information Systems (GIS) software. Correlation network was performed to study the interrelation between the studied variables and the $\mathrm{N}$ application in topdressing. Positive correlations are highlighted in green and negative correlations are represented in red. The line thickness is proportional to the correlation magnitude. Canonical variables were analyzed to study the association between variables and each treatment evaluated. These analyses were performed using the Rbio program (BHERING, 2017).

Figure 1 shows the maps for the variables of the experimental area containing the $\mathrm{N}$ doses applied in topdressing, plant height, dry matter, grain yield, and the vegetation indices NDVI, RE, SAVI, and IV 760/550 IVs. The distribution of the classes of values of vegetation indices and dry matter are very similar in this figure. This association was more evident when the Pearson's correlation network was used between the evaluated variables (Figure 2). All the vegetation indices, except for VI 760/550, are inter-correlated with each other and present a high correlation with shoot dry matter of corn plants.

The VIs NDVI and RE were the most correlated to grain yield and $\mathrm{N}$ doses since they have greater proximity to these variables in the correlation network generated. Similar results were reported by Baio et al. (2018), who investigated the association between vegetation indices and relative deposition of different application rates in corn, which generated higher correlations of these indices with plant dry matter. In addition, the $\mathrm{N}$ doses applied are directly related to corn grain yield. Moreover, linear correlations can be easily interpreted using the graphical network correlation technique. The efficiency of this innovative technique has previously been reported by Silva et al. (2016).

The graphs presented in Figure 3 show the regression equations for the studied variables in function of the $\mathrm{N}$ doses applied in topdressing to corn plants. With the increase of $\mathrm{N}$ doses, the values in a quadratic equation increased for the VIs NDVI (A), REDEDGE (B), and SAVI (C), that is, these VIs presented a saturation close to the maximum $\mathrm{N}$ dose (2240 kg N ha $\left.{ }^{-1}\right)$. Conversely, IV 760/550 has a linear equation, showing that this VI can respond to doses greater than $240 \mathrm{~kg}$ de $\mathrm{N} \mathrm{ha}^{-1}$. For plant height, the quadratic equation showed a good relation to the $\mathrm{N}$ doses in topdressing and to dry matter; however, the latter did not present a good correlation. The observed yield shows that the hybrid used in this study has a high response capacity to $\mathrm{N}$ in topdressing. The highest $\mathrm{N}$ dose also presented the highest yield, and therefore, the equation for this variable is linear. 

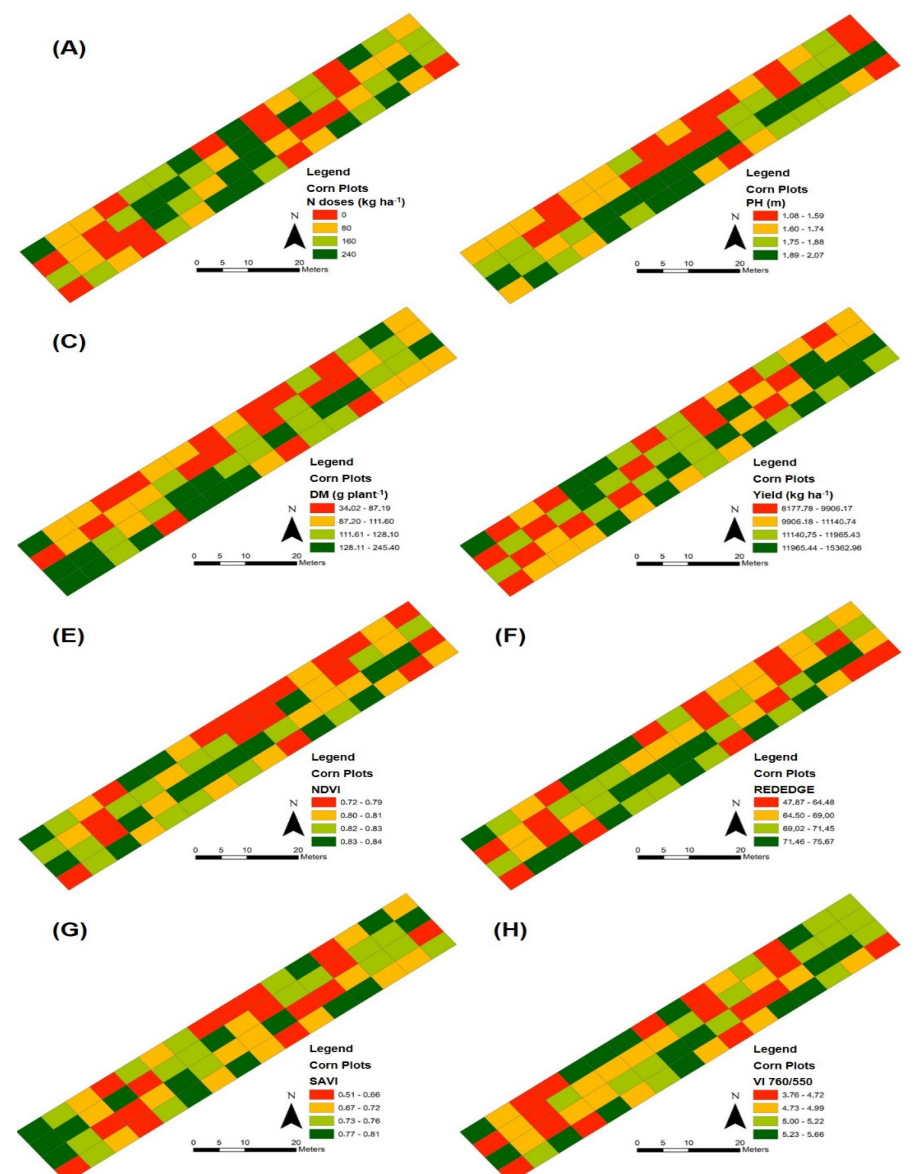

Figure 1. Maps of the experimental area containing $\mathrm{N}$ doses applied in topdressing (A), plant height (B), dry matter - DM (C), yield (D), and VIs NDVI (E), REDEDGE (F), SAVI (G), and VI 760/550 (H).

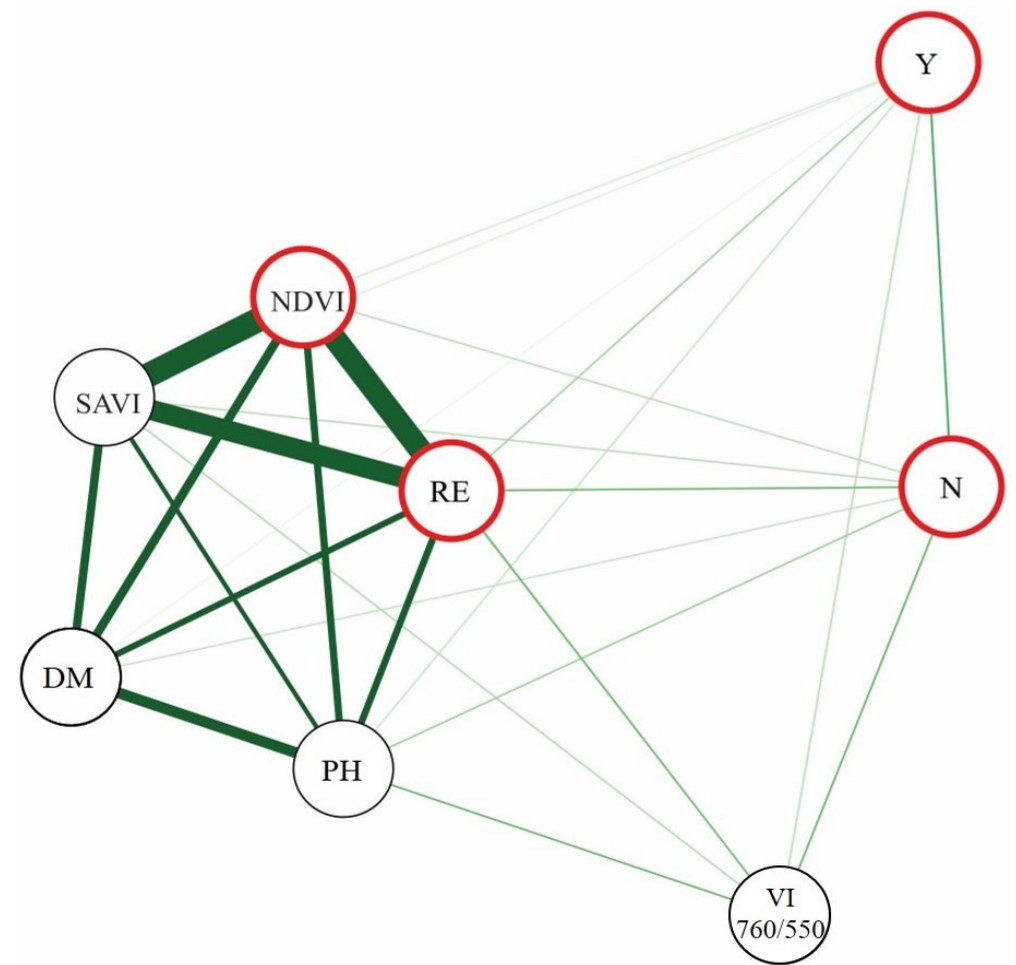

Figure 2. Correlations network between $\mathrm{N}$ doses and the variables plant height $(\mathrm{PH})$, dry matter (DM), the VIs VI 760/550, NDVI, REDEDGE, and SAVI, and yield (Y). 

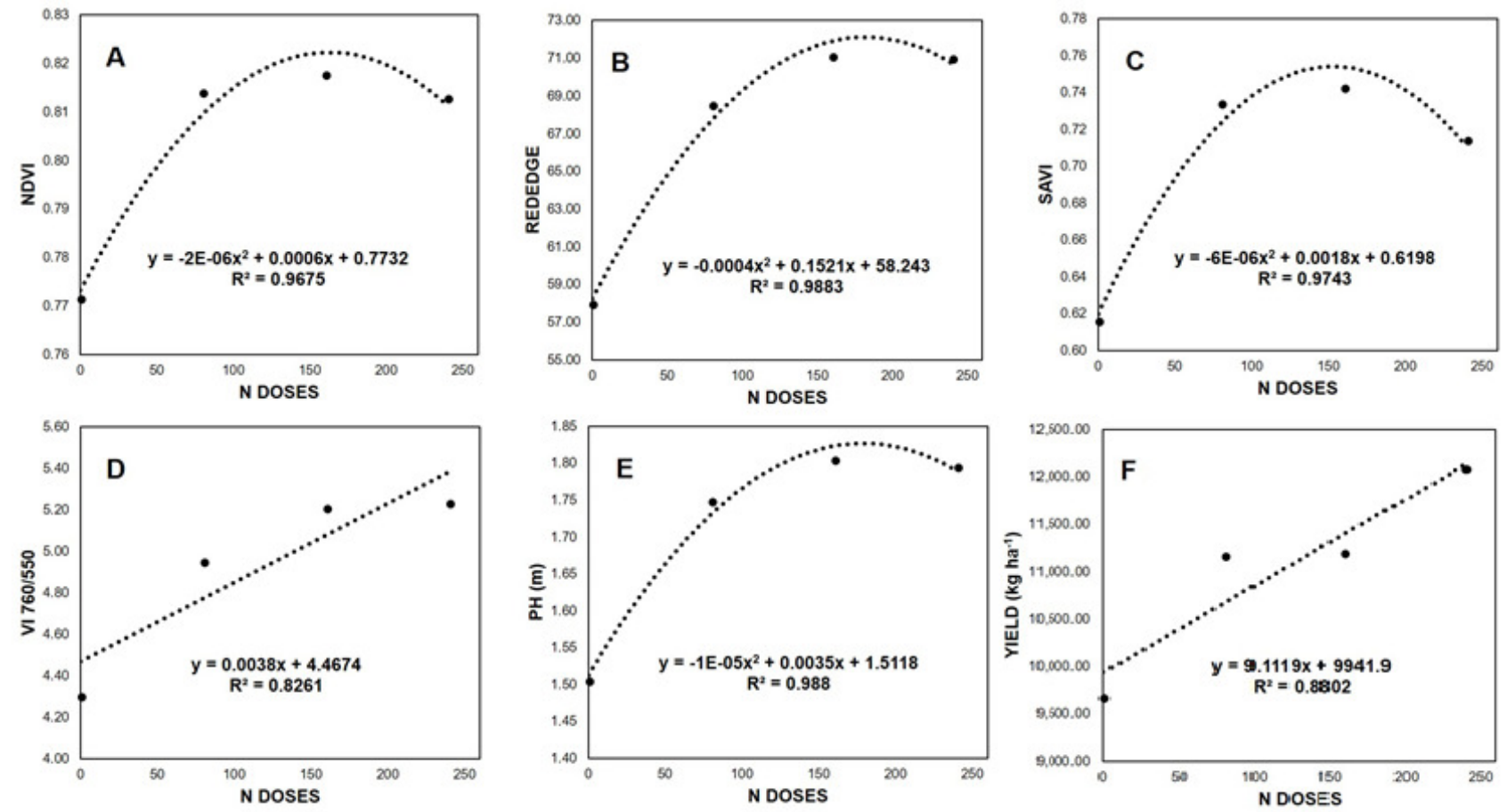

Figure 3. Regression graphs for the variables NDVI (A), REDEDGE (B), SAVI (C), VI 760/550 (D), plant height $(\mathrm{E})$ and yield $(\mathrm{F})$ in $\mathrm{N}$ doses applied in topdressing.

The canonical variables analysis was used to verify the contribution of each variable to the difference between $\mathrm{N}$ doses (Figure 4). This technique is analogous to the principal components analysis but should be preferred when the research has an experimental design (replications). Each canonical variable is a linear combination of the variables used. To represent the scores in a twodimensional graph, the percentage of variance retained in the first two canonical variables must be greater than $80 \%$ (Mingoti 2005). In this work, the variance accumulated in the first two canonical variables was $97.4 \%$, allowing its precise interpretation

The control (dose of $0 \mathrm{~kg} \mathrm{ha}^{-1}$ of N) did not associate with any variable, which was already expected since the genetic material available in the market is highly demanding in $\mathrm{N}$. The vectors grain yield (Y) and NDVI, SAVI, and IV 750/560 are close to the highest $\mathrm{N}$ dose. These results indicate that the highest dose was the most efficient to increase these variables, corroborating the results obtained by Raper and Varco (2015), who observed that NDVI is more associated with cotton plant dry matter when subject to high $\mathrm{N}$ doses. Conversely, the variables $\mathrm{DM}$ and $\mathrm{PH}$ are more associated with the intermediate doses of $\mathrm{N}$ used, which indicates the quadratic behavior of these variables in response to the increasing $\mathrm{N}$ doses applied in topdressing, as also reported by Borges et al. (2006). 


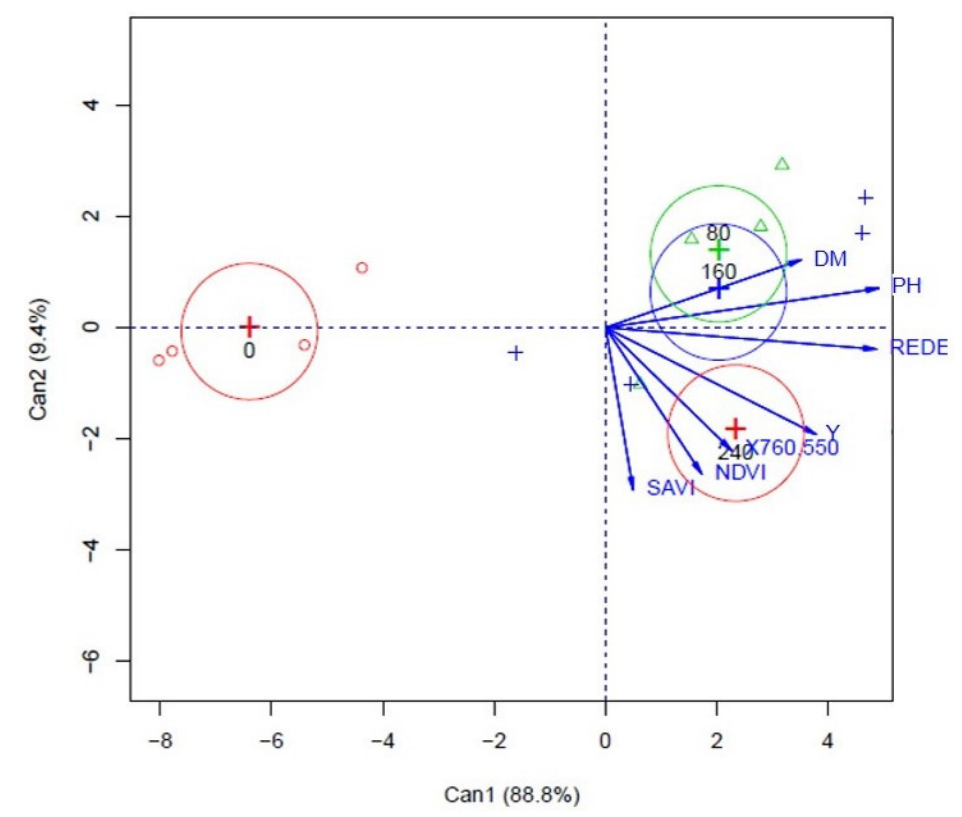

Figure 4. Analysis of canonical variables between the variables PH, DM, VIs (IV760 / 550, NDVI, REDEDGE, and SAVI), Y, and $\mathrm{N}$ doses in topdressing.

\section{CONCLUSION}

The indices NDVI, SAVI, and RE have a high positive association with each other and with the variables plant height and dry matter. NDVI and RE have a positive relationship of moderate magnitude with maize grain yield.

RESUMO: O nitrogênio (N) é o principal nutriente requerido pela cultura do milho, principalmente em solos do Cerrado. Técnicas de sensoriamento remoto podem ser usadas para gerar informações adicionais agora sobre a recomendação de fertilização nitrogenada. Este trabalho investigou a associação de variáveis fenológicas de altura de plantas e matéria seca com os índices de vegetação (IVs) NDVI, REDEDGE, SAVI e IV 760/550 com a produtividade de grãos de milho, sob diferentes doses de N. A semeadura ocorreu em novembro de 2016, com espaçamento de $0,45 \mathrm{~m}$ entre linhas e $60.000 \mathrm{ha}^{-1}$ de população de plantas. Quatro doses de $\mathrm{N}\left(0,80,160\right.$ e $240 \mathrm{~kg}$ de $\left.\mathrm{N} \mathrm{ha}^{-1}\right)$ foram aplicadas no estádio fenológico $\mathrm{V} 4$. O delineamento experimental foi o de blocos casualizados contendo quatro doses de $\mathrm{N}$ em cobertura e 16 repetições. $\mathrm{O}$ sensor óptico ativo Crop Circle ACS-470 foi usado para obter os IVs. Equações de regressão polinomial foram ajustadas entre as variáveis em resposta como doses de N. Posteriormente, foram estimadas como correlações entre variáveis e resultados expressos através da rede de correlações. Por fim, foi realizada uma análise multivariada de variáveis canônicas para entender a inter-relação entre as variáveis e cada dose de $\mathrm{N}$ aplicada. Os índices NDVI, SAVI e RE apresentam alta associação positiva entre si e com as variáveis altura de planta e matéria seca. NDVI e REDEDGE têm uma relação positiva de magnitude moderada com a produtividade de grãos na cultura do milho.

PALAVRAS-CHAVE: Análise multivariada. Sensoriamento remoto. Rede de correlação. Zea mays.

\section{REFERENCES}

BHERING, L. L. Rbio: a tool for biometric and statistical analysis using the R platform. Crop Breeding and Applied Biotechnology, Viçosa, v. 17, p. 187-190, 2017. https://doi.org/10.1590/1984-70332017v17n2s29

BLACKMER, T. M., SCHEPERS, J. S. Use of chorophyll meter to monitor nitrogen status and schedule fertigation for corn. Journal of Production Agriculture, Madison, v. 8, n. 1, p.56-60, 1995. https://doi.org/10.2134/jpa1995.0056 
BORGES, E. A., FERNADES, M. S., LOSS, A., SILVA, E. V., SOUZA, S. R. Acúmulo e remobilização de nitrogênio em variedades de milho. Caatinga, Mossoró, v. 19, n. 3, p. 278-286, 2006.

CONAB. Companhia Nacional de Abastecimento. Acompanhamento da safra brasileira: grãos, décimo levantamento, fevereiro, 2018. Disponível em: <https://www.conab.gov.br/index.php/info-agro/safras $>$. Acesso em 15 de abril de 2018.

ERNANI, P. R. Disponibilidade de nitrogênio e adubação nitrogenada para macieira. Lages: Graphel; 2003.

FANG, H., LIANG, S., HOOGENBOOM, G. Integration of MODIS LAI and vegetation index products with the CSM-CERES-Maize model for corn yield estimation. International Journal of Remote Sensing, v. 32, n. 4, p. 1039-1065, 2011. https://doi.org/10.1080/01431160903505310

MINGOTI, S. A. Análise de dados através de métodos de estatística multivariada. Belo Horizonte: Editora UFNG; 2005.

MLADENOVA, I. E., BOLTEN, J. D., CROW, W. T., ANDERSON, M. C., HAIN, C. R., JOHNSON, D. M., MUELLER, R. Intercomparison of Soil Moisture, Evaporative Stress, and Vegetation Indices for Estimating Corn and Soybean Yields Over the U.S. IEEE Journal of Selected Topics in Applied Earth Observations and Remote Sensing, v. 10, n. 4, p. 1328 - 1343, 2017. https://doi.org/10.1109/JSTARS.2016.2639338

PONZONI, F. J. Comportamento espectral da vegetação. In. Meneses PR, Madeira Netto JS, editores. Sensoriamento remoto - reflectância dos alvos naturais. Brasília, DF: Universidade de Brasília; 2001. p.157-99.

RAPER, T. B., VARCO, J. J. Canopy-scale wavelength and vegetative index sensitivities to cotton growth parameters and nitrogen status. Precision Agriculture, v. 16, n. 1, p. 62-76, 2015. DOI:10.1007/s11119-0149383-4 https://doi.org/10.1007/s11119-014-9383-4

SCHADCHINA, T. M., DMITRIEVA, V. V. Leaf chlorophyll content as a possible diagnostic mean for the evaluation of plant nitrogen uptake from the soil. Journal Plant Nutricion, v. 18, n. 14, p. 27-37, 1995. https://doi.org/10.1080/01904169509364992

SERRANO, L., FILELLA I., PEÑUELAS, J. Remote sensing of biomass and yield of winter wheat under different nitrogen supplies. Crop Science, v. 40, n. 7, p. 23-31, 2000.

https://doi.org/10.2135/cropsci2000.403723x

SHAVER, T. M., KRUGER, G. R., RUDNICK, D.R. Crop Canopy Sensor Orientation for Late Season Nitrogen Determination in Corn. Journal of Plant Nutrition, 2017. DOI: 10.1080/01904167.2017.1346681. https://doi.org/10.1080/01904167.2017.1346681

SILVA, A. R.; RÊGO, E. R.; PESSOA, A. M. S.; RÊGO, M. M. Correlation network analysis between phenotypic and genotypic traits of chili pepper. Correlation network analysis between phenotypic and genotypic traits of chili pepper. Pesquisa Agropecuária Brasileira, Brasília v.51, n.4, p.372-377, 2016. https://doi.org/10.1590/S0100204X2016000400010

TARPLEY, L., REDDY, K. R., Sassenrath-Cole, G. F. Reflectance indices with precision and accuracy in predicting cotton leaf nitrogen concentration. Crop Science, Madson, v. 40, p. 1814-1819, 2000. https://doi.org/10.2135/cropsci2000.4061814x

TUCKER, C. J. Red and photographic infrared linear combination for monitoring vegetation. Remote Sensing Environment, v. 8, n. 1, p. 27-50, 1979. https://doi.org/10.1016/0034-4257(79)90013-0 